\title{
Peran Radio Respon 93.0 FM dalam Pengembangan Pendidikan Karakter Anak di Kecamatan Batang Anai
}

\author{
Fitra, Junaidi Indrawadi \\ Prodi Pendidikan Pancasila dan Kewarganegaraan \\ FIS Universitas Negeri Padang \\ E-mail: fitraramadani204@gmail.com
}

\section{ABSTRAK}

Penelitian ini bertujuan untuk mendeskripsikan peran radio Respon FM dalam mengembangkan pendidikan karakter anak, kendala-kendala yang ditemukan dalam program yang bermuatan pendidikan karakter bagi anak, dan upaya mengatasinya. Di daerah Kabupaten Padang Pariaman, radio Respon FM menjadi radio satu-satunya yang memiliki program siaran bermuatan pendidikan karakter anak. Penelitian ini merupakan penelitian kualitatif dengan pendekatan deskriptif. Hasil penelitian menunjukkan terdapat tiga peran yang dilakukan radio selama proses siaran program, diantaranya menambah pengetahuan anak, mengembangkan potensi diri anak, dan membangun nilai-nilai karakter anak. Kendalakendalanya yaitu kerjasama radio dengan pihak sekolah dan masyarakat yang masih kurang lancar, adanya sebagian anak yang pasif dalam mengikuti siaran acara, kesulitan saat mengkondisikan anak-anak, adanya gangguan alam, dan sulitnya mendapatkan sponsor yang mendukung siaran program radio Respon FM. Upaya yang bisa dilakukan pengelola radio Respon FM yaitu melakukan sosialisasi dengan pihak sekolah dan masyarakat, dan memanfaatkan media sosial yang dimiliki radio Respon FM untuk memberikan informasi terbaru. Oleh karena itu, pihak radio Respon FM hendaknya meningkatkan program-program siaran yang mengandung pendidikan dan menambah dengan kegiatan-kegiatan diluar siaran yang menambah kreatifitas anak pada sekolah-sekolah yang berada di daerah Kecamatan Batang Anai.

Kata Kunci: peranan, media radio, pendidikan karakter anak

\section{ABSTRACT}

This article aims to describe the role of FM response radio in developing children's character education, the constraints found in programs containing character education for children, and efforts to overcome them. In Padang Pariaman Disctrict, Radio Respon FM is the only one radio that has broadcast programs containing children's character education. This research is a qualitative method with a descriptive approach. The results showed that there were three roles played by radio during the program broadcast process, including increasing children's knowledge, developing children's potential, and building children's character values. The obstacles are the radio cooperation with the school and the community which is still not smooth, the existence of some children who are passive in participating in 
program broadcasts, difficulties in conditioning the children, natural disturbances, and difficulty in getting sponsors to support the radio program broadcasts of Respon FM radio. Efforts that Respon FM radio managers can do are socializing with schools and the community, and utilizing social media owned by Respon FM radio to provide the latest information. Therefore, the FM Response radio should increase broadcast programs that contain education and add to activities outside the broadcast that increase children's creativity in schools located in Batang Anai District.

Keywords: role, radio media, character education of children

(c) (7) (?) This work is licensed under the Creative Commons Attribution-ShareAlike 4.0 International License. BY SA 02020 by author. 


\section{PENDAHULUAN}

Pendidikan merupakan upaya memajukan bertumbuhnya budi pekerti (kekuatan batin, karakter) pikiran dan tubuh anak (Samani \& Haryanto,2012: 33). Hal ini berarti pendidikan tidak hanya memberikan pengetahuan saja namun juga mempengaruhi fisik, mental, emosional, serta karakter manusia. Pendidikan adalah membangun manusia yang utuh antara jasmani dan rohani, keseimbangan antara kecerdasan dalam berpikir, sikap, dan serta akhlak mulia yang sesuai dengan tatanan nilai dan norma yang ada di masyarakat dan tuntunan ajaran agama.

Pentingnya pendidikan
karakter didasarkan pada
kenyataan bahwa terdapat
kecenderungan mesotnya
tatanan nilai, norma, dan perilaku
kejahatan seperti kekerasan,
perampokan, atau tawuran yang
sering menghiasi berita dan
menjadi buah bibir masyarakat.
Tidak hanya itu, dikalangan kaum
intelektual masih sering ditemukan
perilaku tersebut. Dalam
kehidupan sehari-hari sudah
semakin menurunnya tatanan nilai
dan kearifan-kearifan lokal, seperti
menurunnya sikap sopan santun
anak terhadap orang tua atau guru,
pelanggaran terhadap adat dan
kebiasaan, perilaku yang kurang

sesuai dengan adat ketimuran, menurunnya sifat gotong royong dan tidak peduli dengan lingkungan sosial. Hal ini menunjukkan perbuatan itu menjadi perilaku yang telah menyimpang dari karakter bangsa.

Proses pembangunan karakter seseorang dipengaruhi oleh faktor yang ada pada diri orang yang bersangkutan yaitu faktor bawaan (nature) dan lingkungan (nurture) tempat ia tumbuh dan berkembang. Dalam hal ini pembentukan karakter dilakukan melalui proses belajar, baik itu secara formal, informal maupun non formal. Komunikasi menjadi unsur penting dalam proses belajar mengajar, dimana dalam proses tersebut terdapat penyampaian pesan antara komunikator dengan komunikan yang dibantu melalui perantara. Perantara itu adalah media. Adapun di dalam dunia pendidikan terdapat banyak macam media yang digunakan untuk mentransfer ilmu pengetahuan. Salah satu media pembelajaran adalah radio.

Radio identik dengan indera pendengaran yang memiliki pengaruh kuat terhadap perasaan pendengarnya. Selain itu radio merupakan media yang dapat mengikuti perkembangan zaman. Hal ini sejalan dengan fungsi radio 
salah satunya sebagai media pendidikan yang tertuang dalam Undang-Undang Nomor 32 tahun 2002 tentang Penyiaran Pasal 4 ayat 1, di mana penyiaran sebagai kegiatan komunikasi massa yang berfungsi sebagai media informasi, pendidikan, hiburan yang sehat, kontrol dan perekat sosial. Fungsi media yang seperti inilah yang dipandang efektif dan memiliki pengaruh besar dalam kemajuan pendidikan di negara kita.

Pada saat ini media radio hanya sedikit yang menyiarkan program tentang pendidikan karakter anak dan cenderung lebih menekankan pada program yang bersifat hiburan. Khususnya di daerah Kabupaten Padang Pariaman, dimana peran radio dalam pendidikan karakter anak belum terwujudkan secara maksimal. Dipilihnya radio Respon FM karena radio yang satu-satunya berada di Kabupaten Padang Pariaman yang khusus memuat program siaran yang bermuatan Pendidikan karakter, yaitu melalui program Lebih Dekat Bersama, Rumah Impian Anak dan Didikan Shubuh. Radio Respon FM beralokasi di Jl. Lintas PadangBukittinggi, Pasar Baru Kasang, Kecamatan Batang Anai. Radio ini bertemakan radio keluarga dan peduli bencana. Alasan radio memuat program khusus pendidikan karakter karena untuk memberikan dukungan kepada sekolah dan masyarakat dalam pembelajaran berbasis audio. Dari penjelasan tersebut, masih kurangnya peranan radio di Kabupaten Padang Pariaman dalam memberikan pendidikan karakter anak melalui siaran-siaran radionya. Dipilihnya radio Respon FM karena radio ini khusus memuat program siaran yang bermuatan pendidikan karakter anak, yaitu melalui program di atas. Berikut ini program-program siaran radio Respon FM, antara lain:

Tabel 1. Nama Program dan Jumlah Pendengar Radio Respon FM

\begin{tabular}{|l|l|c|}
\hline No. & Nama Progam & $\begin{array}{c}\text { Jumlah } \\
\text { Pendengar } \\
\text { (Januari- } \\
\text { Agustus } \\
\text { 2020) }\end{array}$ \\
\hline 1. & $\begin{array}{l}\text { Kopi Pagi } \\
\text { Publik Service }\end{array}$ & 3942 \\
\hline 2. & Klinik Keluarga & 2226 \\
\hline 3. & Memories & 3444 \\
\hline 4. & $\begin{array}{l}\text { Minang Nan } \\
\text { Rancak }\end{array}$ & 3689 \\
\hline 5. & $\begin{array}{l}\text { LebihDekat } \\
\text { Bersama }\end{array}$ & 965 \\
\hline 6. & Nuansa Nagari & 1186 \\
\hline 7. & Respon Islami & 598 \\
\hline 8. & Manca Only & 1029 \\
\hline 9. & Indonesia Only & 2345 \\
\hline
\end{tabular}




\begin{tabular}{|l|l|c|}
\hline 10. & $\begin{array}{l}\text { How are you } \\
\text { Toninght }\end{array}$ & 2833 \\
\hline 11. & $\begin{array}{l}\text { Lets Sing } \\
\text { Tonight }\end{array}$ & 1345 \\
\hline 12. & $\begin{array}{l}\text { Rumah Impian } \\
\text { Anak dan } \\
\text { Didikan Shubuh }\end{array}$ & 670 \\
\hline 13. & Untaian Kata & 1453 \\
\hline 14. & Malam Minggu & 1447 \\
\hline 15. & Ngovi Respon & 1250 \\
\hline 16. & 3 in 1 & 1784 \\
\hline
\end{tabular}

(Sumber: Arsip Radio Respon FM JanuariAgustus 2020)

Masyarakat yang mendengarkan program-program yang bermuatan pendidikan karakter tersebut masih sedikit dibandingkan program radio yang lainnya yaitu pada program lebih dekat bersama 965 orang, program rumah impian anak dan didikan shubuh sebanyak 670 orang, yang program lainnya lebih dari 1000 orang pendengar. Data tersebut diperoleh dari arsip radio Respon FM terhitung mulai dari bulan Januari hingga Agutus 2020.

Penelitian yang relevan dengan peneliti ini diantaranya Androw (2014), menyatakan bahwa dalam meningkatkan pengenalan lingkungan hidup Kepada Warga Kelurahan Sungai Pinang Dalam Kecamatan Sungai Pinang Kota Samarinda, yang mana hasil penelitiannya peran dari radio Heartline ini bertujuan untuk meningkatkan pengenalan lingkungan hidup melalui fungsi media massa.

Kemudian penelitian selanjutnya dari Innayah (2009), yang mana hasil penelitiannya yaitu siaran Pendidikan melalui radio memberikan dukungan pendengar bahwa media radio dapat digunakan sebagai media untuk membantu pembelajaran baik bagi siswa ataupun guru terutama untuk mata pelajaran Bahasa dan sastra Indonesia, Bahasa Inggris IPS, IPA/Sains, Matematika, dan beberapa mata pelajaran lainnya. Siaran radio edukasi membuat pelajaran lebih menarik dan adanya informasi dan pengetahuan yang dapat diambil dari siaran radio. Selanjutnya penelitian dari Mariana (2015), hasil penelitiannya menunjukkan bahwa Balai Pengembangan Media Radio Pendidikan (BPMRP) mampu mengembangkan model dan format media audi pendidikan yang edukatif dan menghibur sekaligus mendidik. Dalam hal ini radio memiliki fungsi sebagai media pendidikan dan hiburan dapat digabungkan untuk menghasilkan program yang ringan didengar tapi sarat informasi.

Berdasarkan uraian permasalahan diatas penelitian ini penting dilakukan karena radio 
Respon FM dapat meningkatkan manfaat dari radio yang tidak hanya sebagai media informasi dan hiburan saja, melainkan juga sebagai media pendidikan bagi anak-anak, orang tua, dan masyarakat yang berada di daerah Kecamatan Batang Anai dan sekitarnya.

\section{METODE PENELITIAN}

Penelitian ini merupakan penelitian kualitatif deskriptif yang bertujuan untuk mendeskripsikan peran radio Respon FM dalam pendidikan karakter anak melalui program-program yang bermuatan pendidikan karakter. Informan dalam penelitian ini berjumlah 7 orang ditentukan dengan menggunakan teknik purposive sampling, yang terdiri dari penanggungjawab radio, penyiar radio, orang tua dan guru. Jenis data dalam penelitian ini terdiri dari data primer dan data sekunder yang diperoleh langssung melalui observasi, wawancara di radio Respon FM, buku-buku, jurnal, skripsi, serta data lainnya yang terkait dengan penelitian ini yang diperoleh melalui studi dokumetasi. Uji keabsahan data menggunakan teknik triangulasi. Analisis data dilakukan dengan tahap reduksi data, display data, dan mengambil kesimpulan/verifikasi data.

\section{HASIL DAN PEMBAHASAN}

Peran Radio Respon FM dalam Pengembangan Pendidikan Karakter Anak

Menurut Androw (2014: 377) peran merupakan suatu fungsi yang dibawakan oleh seseorang yang menduduki suatu posisi tertentu dalam struktur sosial atau organisasi tertentu. Sejalan dengan itu radio Respon FM memiliki peran sesuai dengan fungsi dan kegunaan radio sebagai media informasi, edukasi dan advokasi. Berdasarkan misi dari radio Respon FM salah satunya yaitu: sebagai radio keluarga yang memberikan informasi dan edukasi serta hiburan tentang cara-cara membangun keluarga yang harmonis. Selanjutnya berdasarkan Undang-Undang Penyiaran Nomor 32 Tahun 2002 Pasal mengatakan bahwa penyiaran bertujuan untuk memperkukuh integrasi nasional, terbinanya watak dan jati diri bangsa yang beriman dan bertaqwa, mencerdaskan kehidupan bangsa, memajukan kesejahteraan umum, dalam rangka membangun masyarakat yang mandiri, demokratis, adil dan sejahtera, serta menumbuhkan industri penyiaran Indonesia. Maka dari itu peran radio selain juga media informasi juga sebagai media pendidikan bagi masyarakat. Terdapat tiga peran radio Respon 
FM dalam mengembangkan pendidikan karakter anak di Kecamatan Batang Anai melalui program-program siaran yang bermuatan pendidikan karakter.

\section{Peran Radio Respon FM dalam Menambah Wawasan Anak}

Menurut teori Lickona bahwa untuk membentuk karakter dengan diawali membangun pengetahuan moral (moral knowledge) yaitu berkatian dengan kognitif anak (Muh Idris, 2018:100), berdasarkan hasil penelitian peran radio Respon FM dalam mengembangkan wawasana anak yaitu:

1) Melakukan dialog tanya jawab dengan tenaga pendidik dan anak-anak yang beprestasi

Menurut (Samani dan Haryanto,2012: 148) metode pendidikan karakter dapat dilakukan dengan metode diskusi panel. Metode disikusi panel adalah suatu kelompok kecil yang terdiri dari 3-6 orang mendiskusikan suatu sub topik dari masalah, yang dipimpin oleh satu moderator. Para pendengar (audience) boleh terlibat jika dipersilahkan oleh moderator.

Pada program radio Respon FM metode tersebut digunakan melalui kegiatan dialog bersama pada program lebih dekat bersama. Pada siaran ini pihak radio mengundang bintang tamu yang berpengaruh terhadap bidang pendidikan, seperti tenaga pendidik, siswa dan mahasiswa yang berprestasi. Pada pelaksanaannya melakukan dialog tanya jawab tentang berbagi pengalaman dan motivasi yag positif sehingga bisa menambah wawasan baik itu anak maupun orang tua yang mendnegarkan program tersebut. Selama siaran berlangsung kita dapat melihat bagaimana karakter para tamu undangan dalam menjawab dan menghargai setiap pendapat yang berbeda.

2) Mendengarkan cerita dongeng

Menurut (Samani dan Haryanto, 2012: 148) salah satu metode pendidikan karakter dilakukan dengan cara mendongeng (Telling Story). Mendongeng terdapat pada program Rumah Impian Anak yang disiarkan setiap Sabtu Pagi. Pada acara ini dongeng diceritakan oleh penyiar radio, dimana pendidikan karakter disini terlihat penyiar memmberikan kesimpulan dan pelajaran dari peristiwa yang ada dongeng tersebut, lalu memberikan pengetahuan 
tentang nilai-nilai karakter yang terdapat didalam kisah itu.

3) Mendengarkan tambahan pelajaran dari guru

Menurut (Samani dan Haryanto, 2012: 148) metode pendidikan karakter selanjutnya yaitu menggunakan metode diskusi. Tambahan pelajaran dilakukan pada program siaran didikan shubuh yang dilaksanakan setiap Minggu pagi. Pada acara ini, tambahan pelajaran diberikan oleh seorang guru atau Ustadz yang mendampingi anak-anak dalam proses siaran, seperti memberikan nasehat, kisah, dan motivasi lainnya yang bisa menambah ilmu pengetahuan kepada anak terutama dalam kecintaannya pada agamanya.

Berdasarkan hasil penelitian yang didapatkan bahwa program lebih dekat bersama dan didikan shubuh baru terlaksana semenjak dua tahun terakhir ini. Sedangkan program rumah impian anak sudah ada semenjak mulai berdirinya radio, namun sempat terhenti dikarenakan masalah teknis.

\section{a) Peran Radio Respon FM dalam Mengembangkan Potensi Diri Anak}

$$
\text { Dalam }
$$

Teori

pendidikan karakter Thomas Lickona bhawa proses dan tahapan pendidikan karakter itu juga diikuti dengan perbuatan moral (moral action), dalam hal ini mengembangkan psikomotorik yang berkenaan dengan tindak, perilaku, perbuatan dan sebagainya (Muh Idris, 2018:100).

Berdasarkan hasil penelitian selain memberikan pengetahuan dan menambah wawasan anak, radio Respon FM juga sungguhsungguh dalam mengembangkan potensi diri anak dengan melatih keterampilan berbicara yaitu Public Speaking. Selama proses siaran, bisa terlihat cara anak dalam mengungkapkan pendapatnya, dan menghargai teman-teman yang tampil. Selanjutnya pada program didikan shubuh potensi diri anak dikembangkan dengan anak menjadi MC atau pemandu acara, yang mana proses acara tersebut anak-anak bertanggungjawab untuk mengarahkan dan memimpin acara. Berdasarkan hal tersebut maka dapat diketahui jika peran radio selain menambah wawasan atau pengetahuan anak, juga mengembangkan potensi diri anak melalui bakat dan keterampilan dalam berbicara.

b) Peran Radio Respon FM dalam Mengembangkan Nilai-nilai Karakakter

Pada proses dan tahapan pendidikan karakter selanjutnya yaitu mengembangkan perasaan moral (moral feeling), dalam hal ini berkaitan dengan afektif anak, 
berupa sikap dan tingkah laku, serta nilai-nilai karakter anak (Muh Idris, 2018:100). Nilai-nilai karakter semaunya terdapat 18 karakter diantaranya religius,jujur,toleransi,displin,kerja keras, kreatif, mandiri, drmokratis,rasa ingin tahu, semangat dan kebangsaan, cintah tanah air, menghargai prestasi, bersahabat/komunikatif, cinta damai, gemar membaca, peduli lingkungan, peduli sosial, dan tanggungjawab (Kurniawan, 2013: 41). Namun berdasarkan hasil penelitian terdapat 6 nilai karakter yang dikembangkan, diantaranya yaitu:

\section{Nilai Religius}

Religius adalah sikap yang patuh dalam melaksanakan ajaran agama yang dianutnya (Syamsul, 2013:14). Nilai religius digambarkan melaui program Didikan Shubuh, dimana anak diajarkan untuk berdoa dan bersyukur sebelum memulai siaran dan saat siaran sudah selesai, selanjutnya mendengarkan lagu islami, membacakan ayat AlQur'an yang bertujuan untu menanamkan rasa taat dalam beragama kepada mereka.

\section{Nilai Disiplin}

Disiplin adalah tindakan yang menunjukkan perilaku tertib dan patuh pada berbagai ketentuan dan peraturan (Kurniawan,2013: 41). Nilai disiplin tergambar ketika peserta didik datang tepat waktu dan bisa mengikuti dengan tertib pengarahan dari penyiar dan guru atau Ustadz yang mengawasi.

Nilai Percaya Diri

Percaya diri terlihat dari peserta didik yang berani tampil dan membawakan acara dengan baik, seperti protokol acara mampu menyampaikan dengan bahasa yang baik dan benar. Selanjutnya ketika baca Al-Qur'an dan AsmaulHusna anak-anak berusaha menampilkan yang terbaik dengan suara dan bacaan yang bagus, serta untuk hiburan salah satunya menyanyikan lagu religi dengan penuh penghayatan.

Nilai Tanggung Jawab

Tanggung jawab merupakan sikap atau perilaku yang melaksanakan tugas kewajibannya dengan totalitas (Kurniawan,2013: 41). Tanggung jawab terlihat dari mereka telah mempersiapkan diri dari rumah dan berlatih sebelum tampil di radio tugas-tugas yang telah ditetapkan

\section{Nilai Bersahabat/Komunikatif}

Bersahabat/komuniatif merupakan tindakan yang memeprlihatkan rasa senang berbicara, bergaul, dan bekerja 
sama dengan orang lain. Bersahabat dan komunikatif dapat dilihat dari peserta didik dapat berinteraksi dengan baik dan akrab dengan penyiar radio dan guruguru dengan pembawaan suasana yang menarik ketika siaran.

Semua peran ini sejalan dengan penelitian terdahulu yaitu penelitian Tarida, dkk (2017) yang mana hasil penelitiannya adalah peran dari radio sebagai media pendidikan melalui tiga aspek yaitu pengetahuan (kognitif), sikap (afektif), dan keterampilan (psikomotor).

\section{Kendala-kendala dalam Pelaksanaan Program Siaran Pendidikan Karakter di Radio Respon FM}

Menurut (Heri Gunawan, 2013: 19), kendala-kendala digolongkan menjadi dua bagian, yaitu internal dan eksternal. Berdasarkan hasil penelitian ditemukan kendala-kendala yang dialami oleh radio Respon FM saat proses siaran radio diantaranya yaitu:

a) Sebagaian anak pasif dalam mengikuti proses siaran

Hal menjadi kendala yang bersifat internal yaitu dari dalam diri anak itu snediri. Menurut (Heri Gunawan,2013:19) kendala ini berhubungan dengan kemauan. Kemuan adalah tekad atau keinginan untuk melangsungkan segala ide dan maksud, walau disertai dengan berbagai rintangan dan kesukaran namun sekali-kali tidak menyerah pada rintangan tersebut. Anak yang pasif disebabkan karena mereka baru beradaptasi dengan lingkungan belajar mereka, dimana sebelumnya mereka cenderung hanya mendengarkan guru saja berbicara, namun di radio mereka dituntut untuk bisa berkomunikasi secara aktif dan kreatif, serta mereka harus bisa percaya diri untuk bisa berlatih menampilkan bakat mereka. Ketidakmampuannya berinteraksi secara langsung disebabkan karena faktor kurangnya percaya diri, malu, tidak berani atau takut menyebabkan mereka kesulitan mengikuti proses siarana. Dalam hal ini perlu adanya kerjasama guru dan penyia untuk bisa membuat mereka nyaman.

b) Adanya kesulitan dalam pengkondisian anak-anak saat siaran berlangsung

Hal ini disebabkan naluri mereka sebagai anak-anak yang senang bermain, jadi ketika jeda iklan maka kesempatan itu digunakan mereka untuk bisa berlarian atau sibuk dengan aktivitas mereka sendiri, sehingga ketika siaran dimulai mengakibatkan suara 
kegaduhan, namun hal ini tidak terlalu menjadi kendala yang besar karena masih bisa dikondisikan dengan bekerja sama dengan guru yang bertugas mengawasi.

c) Adanya gangguan teknis

Gangguan teknis seperti mati listrik menyebabkan radio secara langsung juga ikut mati dan tidak dapat difungsikan. Adapun gangguan dari alam yang biasanya sering terjadi seperti hujan deras, angina kencang disertai petir, dan seagainya bisa menyebabkan kerusakan pada jaringan radio, sehingga penyiar tidak berani untu melakukan siaran. Dengan adanya kerusakan teknis tersebut radio tidak bisa mengudara dengan baik. Hal ini sejalan dengan pendapat (Triartanto, 2010: 36-37) yang menyatakan bahwa radio siaran yang berfungsi sebagai media massa tak lepas dari adanya gangguan yang sifatnya teknis karena kekuatan radio siaran adalah bunyi atau suara.

Penelitian ini juga sejalan dengan (Syam'un dan Husnul, 2018: 30) yang mengatakan kendala yang sering ditemukan pada siaran radio berkaitan dengan cuaca. Cuaca merupakan kendala yang dapat menganggu jalannya penyiaran karena bisa menyebabkan listrik mati. Ketika terjadi pemadaman listrik tanpa adanya pemberitahuan, hal ini dapat menyebabkan program siaran tidak lancar.

d) Belum adanya sponsor yang mendukung program bermuatan Pendidikan Karakter Anak

Pihak radio Respon FM masih kesulitan dalam mendapatkan sponsor. Hal ini tidak terlepas dari imbas pandemi virus Corrona yang membuat sejumlah sponsor membatalkan kerjasamanya dengan radio Respon FM. Adapun tujuan dari sponsor ini agar bisa menambah semangat dan motivasi belajar anak dan membuat program siaran pendidikan karakter ini lebih menarik untuk kedepannya.

\section{Upaya-upaya Radio Respon FM dalam Mengatasi Kendala- Kendala yang di temukan}

Menurut KBBI, upaya diartikan sebagai usaha kegiatan yang mengarahkan tenaga, pikiran untuk mencapai tujuan. Menurut (Poerwodarminta, 1986: 574) , upaya adalah usaha untuk menyampaikan maksud, akal, dan ikhtisar. Upaya merupakan segala sesuatu yang bersifat mengusahakan terhadap sesuatu hal supaya dapat lebih berdaya guna dan berhasil guna sesuai dengan maskud, tujuan dan fungsi serta manfaat suatu hal tersebut dilaksanakan. 
Berdasarkan hasil penelitian bahwa upaya yang dilakukan radio Respon FM dalam mengatasi kendala yang ditemukan adalah pertama, mensosialisasikan program radio ke sekolah dan masyarakat sehingga lapisan masyarakat mulai dari anak-anak, remaja hingga orang tuamenumbuhkan minatnya untu mendengarkan radio dan mengetahui manfaat dari radio. Kedua, dengan cara memanfaatkan media sosial yang dimiliki radio Respon FM untuk menyampaikan informasi terbaru dari kegiatan dan program siaran radio.

Adapun media sosial radio Respon FM antara lain Facebook, Instgram, dan Twitter. Dimana yang ketiga ini yang paling banyak di akses adalah Facebook terlihat dari komntar dan tanda like pengikut radio. Selanjutnya radio juga membuka komunikasi melalui via telfon, whattsap, dan website dan hal ini telah berjalan dengan baik serta mendapatkan dukungan yang baik dari pendengar radio. Selanjutnya upaya yang dilakukan untuk membangkit semangat anak dalam belajar yaitu memberikan apresiasi atau penghargaan kepada mereka yang diundang dan berani tampil di radio.

\section{KESIMPULAN}

Berdasarkan pembahasan di atas, maka peran radio Respon FM dalam mengembangkan pendidikan karakter anak di Kecamatan Batang Anai terbagi tiga yaitu menambah wawasan anak melalui siaran program lebih dekat bersama dengan mendatangkan narasumber yang dapat membangkitkan motivasi anak dalam belajar, mengembangkan potensi diri anak yaitu dengan melatih keterampilan anak dalam berbicara dan berani menampilkan bakatnya dalam public speaking, dan mengembangkan nilai-nilai karakter pada anak yang terdiri dari, karakter religius, disiplin, tanggung jawab, percaya diri, dan bersahabat/komunikatif.

Kendala yang ditemukan seperti anak yang masih pasif untuk belajar melalui media radio, gangguan teknis dari alam, dan belum mendapatkan sponsor yang mendukung program siaran radio yang bermuatan pendidikan karakter anak. Oleh karena itu, pihak radio Respon FM hendaknya meningkatkan program-program siaran yang mengandung pendidikan dan lebih meningkatkan kerjasama dengan orang tua, guru, maupun lembaglembaga pendidikan, serta menambah dengan kegiatankegiatan diluar siaran yang menambah kreatifitas anak pada sekolah-sekolah yang berada di daerah Kecamatan Batang Anai. 


\section{DAFTAR PUSTAKA}

Androw. 2014. Peran radio Hartline 94,4 FM dalam Meningkatkan Pengenalan Lingkungan Hidup kepada Warga Kelurahan Sungai Pinang dalam Kecamatan Sungai Pinang Kota Samarinda. Jurnal Ilmu Komunikasi, 2 (3): 374-385.

Gunawan, Heri. 2017. Pendidikan Karakter Konsep dan Impelentasi. Bandung: Alfabeta.

Innayah. 2014. Partisipasi Stasiun radio dalam Menyiarkan Konten Pendidikan. Jurnal Teknodi, 8 (2): 217-225.

Kurniawan, Syamsul. 2013. Pendidikan Karakter Konsepsi $\mathcal{E}$ Implementasinya secara Terpadu di Lingkungan Keluarga, Sekolah, Perguruan Tinggi, dan Masyarakat. Yogyakarta: Ar-Ruzz Media.

Mariana, Susanti. 2015. Pendidikan dan Hiburan dalam Drama Pendidikan (Analisis Isi Naskah Drama Radio "Generasi Edu"). Jurnal Pekomnas,18 (1): 15-26.

Muh Idris. 2019. Pendidikan Karakter: Perspektif Islam dan Thomas Lickona. Jurnal Manajemen Pendidikan Islam, 7 (1): 77-102.

Poerwadarminta W.J.S. 1986. Kamus Umum Bahasa Indonesia. Jakarta: Balai Pustaka.
Triartanto. 2010. Broadcasting Radio : Panduan Teori dan Praktek. Pustaka Book: Yogyakarta. Samani \& Hariyanto. 2012. Konsep dan Model Pendidikan Karakter. Bandung: PT Remaja Rosdakarya.

Syam'un dan Husnul. 2018. Program Balla Kayua Sebagai Penyalur Budaya (Studi Kasus pada siaran Radio Gama di Kabupaten Gowa). Jurnal Al-Khitabah, 5 (2): 17-32.

Tarida,dkk. 2017. Peran siaran radio sebagai media pemenuhan kebutuhan informasi bagi orang tua untuk anak (Studi kasus pada program siaran Breakfast Club di Mom and Kids Radio) diakses tanggal 29 Agustus 2020.

Undang-Undang Nomor 32 tahun 2002 Tentang Penyiaran.

Kamus Besar Bahasa Indonesia Edisi: Revisi diakses tanggal 22 November 2020. 